\title{
Evaluation of Deterioration Index in Soil Nutrients due to Cultivation of Different Cocoa Species in Southwest Nigeria
}

\author{
*AFOLAYAN, OS; ODERINDE, FO
}

\author{
Department of Geography and Environmental Management, College of Social and Management Sciences, Tai Solarin University of \\ Education, P.M.B. 2118 Ijebu-Ode, Ogun State, Nigeria. \\ *Corresponding author Email: afosam84@gmail.com; Phone: 234-7038424974
}

\begin{abstract}
The study uses the index of soil deterioration to evaluate the soil nutrient status as a result of cultivating different species of cocoa in Idanre, Odigbo and Owo areas of Southwest Nigeria. Soil samples were randomly taken and analyzed using standard methods. The results indicated variation in soil properties under both species due to the difference in nutrient uptake. Results also show that soil properties deteriorate more under hybrid than on indigenous cocoa plantations. Amongst the nutrients, phosphorus had the highest rate of increase for indigenous than hybrid cocoa plantations. Average weight of cocoa pod ranges from 0.50 to $0.60 \mathrm{~kg}$ in indigenous and 0.56 to $0.85 \mathrm{~kg}$ in hybrid species. Removal of the nutrients is directly linked to the rapid development of the hybrid species, their weight and size as opposed to the indigenous species. The study recommends seasonal relocation of podhusk deposit sites and spread of accumulated podhusk across the farm, application of chemical and podhusk fertilizer, and development of cocoa variety with low soil fertility tolerance.
\end{abstract}

DOI: https://dx.doi.org/10.4314/jasem.v22i4.20

Copyright: Copyright (C) 2018 Afolayan and Oderinde. This is an open access article distributed under the Creative Commons Attribution License (CCL), which permits unrestricted use, distribution, and reproduction in any medium, provided the original work is properly cited.

Dates: Received: 14 February 2018; Revised: 12 April: 2018; Accepted: 21 April 2018

Keywords: Cocoa, hybrid, indigenous, species

Soil varies in terms of physicochemical properties and nature of the crops grown over the years. Also, its replenishment is the function of soil type, species of crops grown and management strategies. Annual crops except leguminous ones virtually siphon nutrients from the field contrary to the fruiting-tree crops like cocoa and kola that allow integration of shaded trees. The role of litterfall (cocoa and shaded trees) in recycling nutrient from the subsoil via roots into the plant parts and back to the soil has been the essence of nutrient self-sustenance mechanism in cocoa agroforestry especially in tropical rainforest regions (Hartemink, 2005). However, not all nutrients extracted from the plant environment are usually released at the same time and rate through litterfall. Nutrient mobility varies from one pool to the others. Based on Gersmehl (1976) nutrient cycling model, soil litter and biomass are the three major compartments of nutrient cycling in tropical rainforest ecosystems. The rate of decomposition and mineralization of soil organic matter varies not only with climate, but also with variations in soil textural composition (Aweto, 2001). Tropical rainforests tend to concentrate proportionately more calcium, silica, sulfur, iron, and sodium but less potassium and phosphorus than temperate forests (Robert, 1996). Concentration of all major nutrients are higher on more fertile soils, exemplified by the Panamanian forest, than on the infertile oxisols/ultisol soils that are especially low in phosphorus, potassium, and calcium (Vitousek and Sanford, 1986). It follows that tropical forests on more fertile soils return more litter with higher concentration of nutrients to the forest floor than do forests on other soils. Most soils under cocoa had a lower fertility when compared to primary forests, although soil chemical properties seem to settle at equilibrium levels (Hartemink, 2005).

Soil nutrient status in cocoa plantation of different varieties with record of age is better assessed with the aid of deterioration index. According to Ekanade (1985), the index of deterioration is the difference between the mean values of soil properties in the forest on the one hand and the cocoa plant communities, on the other. Computation of the index of deterioration is premised on the assumption that the status of any soil property in a cultivated plant community was once the same as that under the forest before the commencement of cultivation; indicating that the mean level of a soil property in the forest is regarded as the optimal level (Ekanade, 2011). Also, the implication of an index of deterioration in this study indicates that nutrient status of soil in the plantations seems to be stable before the area was exposed to 
human activities, in other words, the effects of plantation on the edaphic component is being reflected and affected. Deterioration index with negative (-) values indicate an appreciation in soil property while positive (+) value shows depreciation in soil property. However, from the context, this study intends to evaluate the differences in soil nutrient deterioration with respect to different species of cocoa grown in southwest Nigeria.

\section{MATERIALS AND METHODS}

Study Area: Ondo State is located in the southwestern Nigeria approximately between $5^{\circ} 45^{\prime}$ and $7^{\circ}$ $52^{\prime} \mathrm{N}$ and longitude $4^{\circ} 20^{\prime}$ and $6^{\circ} 05^{\prime} \mathrm{E}$. The State is bounded on the east by Edo and Delta States, on the west by Ogun and Osun States, on the north by Ekiti and Kogi State and to the south by the Bight of Benin and Atlantic Ocean (Figure 1).

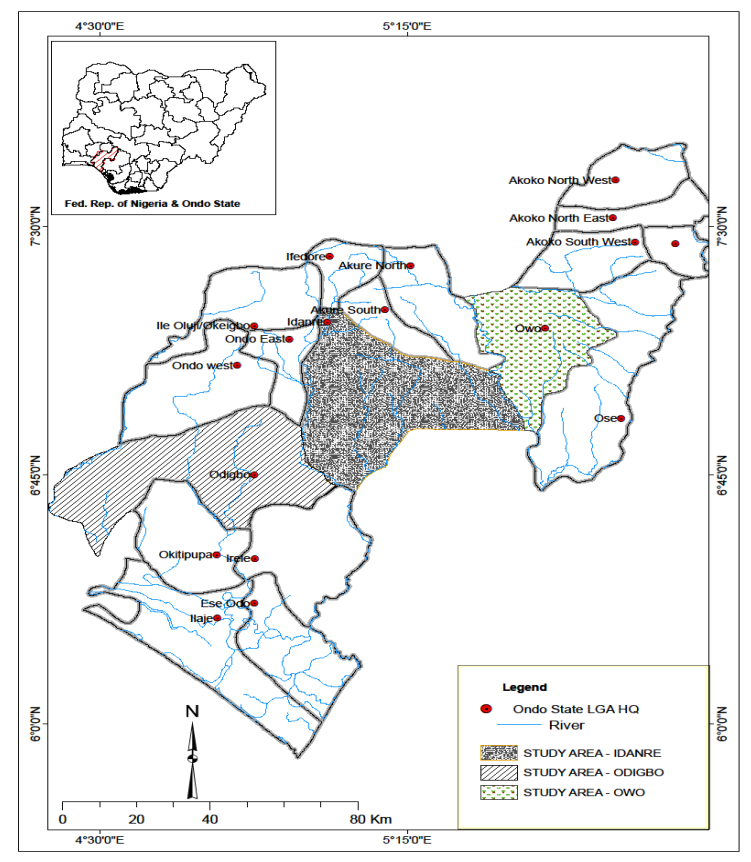

Fig 1: Ondo State showing Local Government Areas Source: Modified from Nigerian Geological Survey Agency (2006).

The State covers an estimated area of $15,820 \mathrm{~km}^{2}$ .Three communities out of the eighteen existing Local Government Areas (Alade; Idanre, Ijegunma; Owo, Oniparaga; Odigbo) in Ondo State were chosen for the study based on their annual rate of cocoa production over the decades. The climate of the area is of lowland tropical rainforest type, with distinct wet and dry seasons. The rainy season normally commence from March to October with double maxima rainfall in June/July and slight dry season between November and March. The area is characterized with mean annual rainfall of about $2000 \mathrm{~mm}$, but the three months of November - January may be relatively dry. The study area has a mean monthly temperature of $27^{\circ} \mathrm{C}$ with a range of $2^{\circ} \mathrm{C}$, while the mean relative humidity is over $70 \%$. The vegetation of the area is classified under rainforest agro-ecological zone, an ideal belt for the production of tree crops. Its soil is characterized by very deep and well-drained; loam sandy surface, sandy clay and clay loamy subsoil. Basement complex rock is the main type of the area bedrock geology.

Sample Collection: Indigenous and hybrid cocoa farms of average age of 55 years were selected for study in the area based on the annual rate of cocoa production record over the years. The main variable considered for this study was soil from an indigenous and hybrid cocoa farms. Twelve (12) soil samples were randomly selected from $25 \mathrm{~m}$ by $25 \mathrm{~m}$ quadrat plot in each of the farms in Idanre, Owo and Odigbo. The samples were collected from two different depths 0$15 \mathrm{~cm}$ and $15-30 \mathrm{~cm}$ considered as topsoil and subsoil, respectively. Sampling was limited to this zone due to the fact that the most feeding roots of cocoa are concentrated in that depth (Wood and Lass, 1984; De Oliveira and Valle, 1990; Aikpokpodion, 2010).

Sample Preparation and Analysis: Soil samples were subjected to laboratory routine using standard procedures at Step B Central Research Laboratory, Federal University of Technology, Akure. Soil samples were air-dried, thoroughly mixed-up together, sieved with $2.0 \mathrm{~mm}$ sieve and analyzed for particle size distribution and physicochemical parameters. Soil $\mathrm{pH}$ was determined potentiometrically in $0.01 \mathrm{M}$ calcium chloride solution ratio of 1:2 according to Peech (1965). Organic carbon was determined using the chromic acid digestion method (Walkley and Black, 1934). Extract of soil sample leached with 1NB ammonium acetate were used to determine the concentrations of exchangeable cations, thereafter $\mathrm{Ca}^{2+}, \mathrm{K}^{+}$, and $\mathrm{Mg}^{2+}$ were determined by Atomic Absorption and $\mathrm{Na}^{+}$was determined by flame photometry. Total nitrogen was determined by the Kjedahl Method and available phosphorus was determined by the Bray method (Jackson, 1970). Extractable micronutrients ( $\mathrm{Zn}, \mathrm{Cu}, \mathrm{Fe}$ and $\mathrm{Mn}$ ) were measured after extraction with 0.02 M EDTA using Atomic Absorption Spectrophotometer (Isaac and Korber, 1971). Laboratory results were subjected to descriptive statistics using deterioration index. The mean value of forest soil property minus the mean value of cocoa soil property, divided by the mean value of forest soil property, multiplied by 100.Deterioration index with negative (-) values indicate an appreciation in soil property while positive (+) value shows depreciation in soil property under cocoa ecosystem. 


\section{RESULTS AND DISCUSSION}

Deterioration index in Indigenous Cocoa Species: The result shows that on the topsoil in Idanre area, there existed improvement in silt $(-25 \%)$, nitrogen ($21.15 \%), \mathrm{pH}(-6.73 \%), \mathrm{P}(-181.42 \%)$ and $\mathrm{Fe}(-4.88)$ and deterioration of both physical and chemical properties ranged from 0 (clay, $\mathrm{EC}, \mathrm{K}$, and $\mathrm{Mg}$ ) to $52.42 \%(\mathrm{Ca})$. It was also observed from the subsoil in Idanre area, that soil properties deterioration ranged from 0 (EC, $\mathrm{Mg}$ and $\mathrm{Na}$ ) to $58.38 \%$ (EA) while increase in these properties ranged from $-7.77 \%(\mathrm{pH})$ to $-92.09 \%$ (base saturation). The concentration of nitrogen in the topsoil (-21.15) is less than that of subsoil (-36.53) (Table 1). This may be attributed to the effect of leaching of nitrate-nitrogen. Nitrate-N according to Schroth and Sinclair (2003) is easily lost from agricultural soils through leaching. Recycling of nitrate-N from the subsoil can be an important function of trees in agroforestry system (Barrios and Schroth, 2003).

Almost all soil properties on the topsoil in Owo area increased when compared with secondary forest except silt (11.11) and $\mathrm{pH}$ (7.18). Increase in soil properties ranged from $-3.94 \%$ (sand) to $152.63 \%$ (Ca). Increase in soil chemical properties was more than $100 \%$ in nutrient like $\mathrm{K}, \mathrm{Ca}, \mathrm{CEC}, \mathrm{EA}, \mathrm{H}^{+}$and $\mathrm{P}$ respectively compared to physical properties. Chemical properties such as K (-33.33), CEC (-1.32), EA (-13.52), $\mathrm{H}^{+}(-17.08)$ and $(-121.3)$ increased in the topsoil in Odigbo while silt -25$)$, clay $(-19.6)$, base saturation (-102.06), organic matter (-47.59), nitrogen $(-23.63)$ and $\mathrm{pH}(-3.90)$ increase in the subsoil (Table 1). Availability of many nutrients in the soil in Owo area may be linked to the clay loamy type of soil that reduces leaching unlike Idanre and Odigbo that are sandy loam. Worthy of note is $\mathrm{Mg}$, which is the most depreciated on all farms, and tree crops tend to be more sensitive to $\mathrm{mg}$ deficiency than annual crops. Low Mg contents according to von Uexkull (1986) are common in acid soils, and $\mathrm{Mg}$ deficiency can be induced by high aluminium contents or by $\mathrm{K}$ fertilization. Calcium increase was revealed to be higher $(-52.63 \%)$ and subsoil (100\%) among all other exchangeable bases in the study area; thus, this conforms with the observation made by Aweto et al. (1992) that Ca concentration was the highest of other exchangeable bases on a forest alfisol in south western Nigeria. It may be attributed to the clay loamy soil of the area and the influence of tree crops in rainforest. Some trees promote the accumulation of cations in the topsoil, presumably through efficient uptake by a large root system and subsequent release from litter (Schroth et al., 2003). According to Fisher (1995), several tree species increased the calcium and potassium contents in the topsoil of a degraded rainforest site. $\mathrm{Ca}$ is also immobile in plant, moderately mobile in soil and the most available cations in the soil.

Soil Properties under Hybrid Cocoa Plantations: The study revealed that the sand content in hybrid cocoa plantations ranged from $28.80 \%$ in the subsoil in Idanre to $52.80 \%$ in the topsoil in Idanre and Odigbo. Idanre has an average mean of $40.80 \%$ of sand; Owo has $46.80 \%$, while Odigbo has $50.80 \%$ respectively. The silt ranged from $16 \%$ to $20 \%$ with average values $17 \%$ to $19 \%$ as well. The mean concentration of clay varied from $32.20 \%$ to $42.20 \%$ of the soil composition. Sandy soil dominates the topsoil while clay soil dominates the soil structure and composition across the hybrid cocoa plantations. Under hybrid cocoa plantations, $\mathrm{P}$ from chemical and $\mathrm{Zn}$ from trace element were the most concentrated properties in the soil. Conversely, $\mathrm{Mn}, \mathrm{K}, \mathrm{Mg}$ and $\mathrm{Na}$ were the least concentrated properties in the soils examined.

In Idanre, $P(7.91 \mathrm{mg} / \mathrm{kg})$ was the nutrient with the highest concentration among the soil chemical properties while $\mathrm{N}(0.52 \%)$ was the least. $\mathrm{H}^{+}$ $(3.79 \mathrm{cmo} 1 / \mathrm{kg})$ accounts for the highest among the cations while $\mathrm{K}, \mathrm{Mg}$ and $\mathrm{Na}$ were the least with average value of $0.01 \mathrm{cmo} 1 / \mathrm{kg}$ each. Mn was the least concentrated among the trace elements in the three selected farms under hybrid cocoa plantations. In Owo, P $(14.85 \mathrm{mg} / \mathrm{kg})$ has the highest mean value while $\mathrm{N}(0.52 \%)$ has the least concentration of the chemical properties. $\mathrm{Mg}$ and $\mathrm{Na}(0.01 \mathrm{cmo} 1 / \mathrm{kg})$ had the least concentration among the cations and $\mathrm{Mn}$ $(0.24 \mathrm{mg} / \mathrm{kg})$ from the trace elements.

Deterioration index in hybrid cocoa plantations: In hybrid cocoa plantations, there were no changes in all textural composition under the topsoil in Idanre and Odigbo while silt and clay increased in the subsoil in Idanre and Owo. It ranged from -6.41 (clay) in Owo topsoil to -66.66 (silt) in the subsoil. Deterioration index in all locations, especially in topsoil ranged from 0 to $3.94 \%$ (Owo) topsoil. Organic matter (-30.29) and organic carbon (-30.33) increase on the topsoil in Owo were similar under hybrid. The same situation was applied to organic matter (-73.28) and nitrogen (73.03) under hybrid cocoa plantation. Also, subsoil under indigenous cocoa farms in Owo has organic matter and organic carbon of -84.13 and -83.47 respectively. Similarity the increase and decrease were most likely due to the activity of soil microorganisms. Accumulation of organic matter and carbon may be attributed to the high clay content in Owo while that of nitrogen may be due to the activity of nitrogenous trees. Soil organic matter content may increase with time under agroforestry system of cocoa. According to 
Beer et al. (1998), over a 10 year period following conversion of sugarcane fields to cocoa plantations, SOM increased by $21 \%$ under pruned leguminous Erythrina poeppigiana and by $9 \%$ under unpruned nonleguminous Cordia alliodora. Under hybrid cocoa plantations, the most increased soil nutrient among the essential nutrients was phosphorus with an index value of -213.01 (Owo topsoil), -208.71 (Odigbo topsoil), 196.19 (Idanre topsoil) and -127.20 (Owo subsoil). From indigenous cocoa plantations, phosphorus $(\mathrm{P})$

Table 1: Deterioration Indices for Soil Properties under Indigenous Cocoa Plantations.

\begin{tabular}{|c|c|c|c|c|c|c|}
\hline & \multicolumn{2}{|c|}{ Idanre } & \multicolumn{2}{|l|}{ Owo } & \multicolumn{2}{|c|}{ Odigbo } \\
\hline Soil Properties & T op soil & Subsoil & Topsoil & Subsoil & T op soil & Subsoil \\
\hline Sand $(\%)$ & 7.57 & 29.41 & -3.94 & 16.39 & 7.58 & 29.41 \\
\hline Si1t $(\%)$ & -25.00 & -25.00 & 11.11 & -33.33 & -25.00 & -25.00 \\
\hline Clay (\%) & 0.00 & -19.68 & -12.82 & 16.33 & 0.00 & -19.68 \\
\hline BS $(\%)$ & 19.26 & -92.09 & -12.82 & -24.42 & $58.46^{\circ}$ & -102.06 \\
\hline$O C(\%)$ & 14.17 & $50.00^{\circ}$ & -73.28 & -83.47 & -20.62 & 8.71 \\
\hline$N(\%)$ & -21.15 & -36.53 & -73.03 & -10.34 & 9.09 & -23.63 \\
\hline $\mathrm{pH}$ & -6.73 & -7.77 & 7.18 & 0.34 & 0.68 & -3.90 \\
\hline $\mathrm{EC}(\mathrm{d} s / \mathrm{m})$ & 0.00 & 0.00 & 0.00 & 0.00 & 0.00 & 0.00 \\
\hline $\mathrm{K}(\mathrm{cmol} / \mathrm{kg})$ & 0.00 & 33.33 & -100.00 & -33.33 & -33.33 & 0.00 \\
\hline $\mathrm{Mg}(\mathrm{cmol} / \mathrm{kg})$ & 0.00 & 0.00 & 0.00 & 0.00 & 0.00 & 0.00 \\
\hline $\mathrm{Ca}(\mathrm{cmol} / \mathrm{kg})$ & $52.72^{\circ}$ & 5.26 & -152.63 & -100.00 & $57.47^{\circ}$ & -31.25 \\
\hline $\mathrm{Na}(\mathrm{cmol} / \mathrm{kg})$ & $50.00^{\circ}$ & 0.00 & 0.00 & 0.00 & $50.00^{\circ}$ & 0.00 \\
\hline$C E C(\mathrm{cmol} / \mathrm{kg})$ & 37.06 & $52.29^{\circ}$ & -112.40 & 25.95 & -11.32 & 38.73 \\
\hline E.A $(\mathrm{cmol} / \mathrm{kg})$ & 33.77 & $58.38^{\circ}$ & -107.89 & 23.52 & -13.52 & 41.83 \\
\hline $\mathrm{H}^{-}(\mathrm{cmol} / \mathrm{kg})$ & 35.55 & 58.06 & -104.54 & 22.64 & -17.08 & 41.66 \\
\hline $\mathrm{P}(\mathrm{mg} / \mathrm{kg})$ & -181.42 & 44.55 & -102.42 & 2.01 & -121.33 & -21.58 \\
\hline $\mathrm{Zn}(\mathrm{mg} / \mathrm{kg})$ & 20.00 & 24.84 & -3.08 & -4.82 & 9.52 & 5.56 \\
\hline $\mathrm{Cv}(\mathrm{mg} / \mathrm{kg})$ & 6.57 & -11.11 & -1.43 & -3.62 & 2.17 & 0.73 \\
\hline $\mathrm{Fe}(\mathrm{mg} / \mathrm{kg})$ & -4.88 & -6.92 & 20.83 & 11.97 & 8.96 & 2.96 \\
\hline $\mathrm{Mn}(\mathrm{mg} / \mathrm{kg})$ & $56.25^{\circ}$ & 30.00 & -10.00 & 15.78 & 30.76 & 21.05 \\
\hline
\end{tabular}

Source: Authors (2016) *: High pattern of deterioration

Table 2: Deterioration Indices for Soil Properties under Hybrid Cocoa Plantations

\begin{tabular}{|c|c|c|c|c|c|c|}
\hline Soil Properties & \multicolumn{2}{|l|}{ Idanre } & \multicolumn{2}{|l|}{ Owo } & \multicolumn{2}{|l|}{ Odigbo } \\
\hline & Topsoil & Subsoil & Topsoil & Subsoil & Topsoil & Subsoil \\
\hline Sand $(\%)$ & 0.00 & 29.41 & 3.94 & 32.79 & 0.00 & 3.93 \\
\hline Silt (\%) & 0.00 & -25.00 & 0.00 & -66.66 & 0.00 & 0.00 \\
\hline Clay (\%) & 0.00 & -18.51 & -6.41 & -30.61 & 0.00 & -6.41 \\
\hline BS (\%) & $79.23^{*}$ & $159.80^{*}$ & -35.79 & -50.74 & $83.54^{*}$ & -164.18 \\
\hline $\mathrm{OC}(\%)$ & $54.85^{*}$ & 3.35 & -30.33 & 4.95 & 20.17 & 4.10 \\
\hline $\mathrm{N}(\%)$ & -3.84 & 3.84 & 30.37 & 15.51 & 16.66 & 9.09 \\
\hline pH & -10.74 & -0.19 & -1.30 & -2.38 & -5.67 & -1.41 \\
\hline $\mathrm{E} \mathrm{C}(\mathrm{ds} / \mathrm{m})$ & 0.00 & 0.00 & 0.00 & 0.00 & 0.00 & 0.00 \\
\hline $\mathrm{K}(\mathrm{cmol} / \mathrm{kg})$ & 33.33 & $66.66^{*}$ & -100.00 & 33.33 & 33.33 & 33.33 \\
\hline $\mathrm{Mg}(\mathrm{cmo} 1 / \mathrm{kg})$ & 0.00 & 0.00 & 0.000 & 0.00 & 0.00 & 0.00 \\
\hline $\mathrm{Ca}(\mathrm{cmo} 1 / \mathrm{kg})$ & $58.18^{*}$ & -136.84 & -45.45 & -75.00 & $67.81^{*}$ & -81.25 \\
\hline $\mathrm{Na}(\mathrm{cmo} 1 / \mathrm{kg})$ & $50.00^{*}$ & -100.00 & 0.00 & 0.00 & $50.00^{*}$ & -100.00 \\
\hline $\mathrm{CEC}(\mathrm{cmo} 1 / \mathrm{kg})$ & -112.93 & 21.40 & -101.45 & 33.62 & -108.96 & 27.62 \\
\hline E.A (cmo1/kg) & 7.55 & 35.40 & -109.64 & 26.64 & -31.76 & 31.37 \\
\hline $\mathrm{H}^{+}(\mathrm{cmol} / \mathrm{kg})$ & -155.81 & 35.48 & -95.45 & 24.52 & -142.40 & 30.55 \\
\hline $\mathrm{P}(\mathrm{mg} / \mathrm{kg})$ & -196.19 & 23.35 & -213.01 & -127.20 & -208.71 & -17.48 \\
\hline $\mathrm{Zn}(\mathrm{mg} / \mathrm{kg})$ & 9.09 & -18.01 & -53.85 & 13.79 & -19.05 & 13.89 \\
\hline $\mathrm{Cu}(\mathrm{mg} / \mathrm{kg})$ & -38.69 & 9.63 & -33.57 & 1.45 & -36.96 & 6.57 \\
\hline $\mathrm{Fe}(\mathrm{mg} / \mathrm{kg})$ & -11.38 & 13.08 & 9.02 & 6.34 & 0.00 & 8.89 \\
\hline $\operatorname{Mn}(\mathrm{mg} / \mathrm{kg})$ & 43.75 & -15.00 & -55.00 & 5.26 & 7.69 & -5.26 \\
\hline
\end{tabular}

The study showed that phosphorus appreciates more than other nutrients, especially in topsoil than subsoil which may be attributed to the high content of the immobilized phosphorus deposited through litterfall before being leached into the subsoil. This may be as a result of large amount present in leaf litter. A large part of $\mathrm{P}$ in cocoa ecosystems, according to Hartemink (2005), is found in the vegetation and in the litter, whereas the amount of $\mathrm{P}$ in the soil is low. Also, leaching is very negligible under mature cocoa plantation. Increase in phosphorus and trace elements, especially copper and manganese under both species may be attributed to the seasonal application of agro-based chemicals to forestall the debilitating diseases and aid the normal development as well as ripping of mature pod. The high concentration of copper sulphate specifically promotes an increase in soil copper under cocoa plantation.

The content of trace element uptake in cocoa tree is minimal and seasonal application of chemical to combat pathogen contributed immensely to their accumulation compared to macronutrients. Also, some of the micronutrients according to Henry (1990) are weathered from the parent material. An increase in nitrogen content is a direct influence of nitrogenous shaded trees commonly incorporated into cocoa plantations.

From the findings, however, soil properties deteriorate more under hybrid than on indigenous cocoa plantations based on the results from the computed index of deterioration. Similarly, nitrogen and potassium increased under indigenous plantations than hybrid while phosphorus increased in hybrids than indigenous cocoa plantations in the study area. From Table 1, it was obvious that the chemical properties in the topsoil were mostly affected. 
This is in line with Ekanade's (2011) result that once the tropical rainforest is removed, soil properties, especially the chemical properties deteriorate under cocoa with time. When the forest is removed and replaced by field or tree crops, the balance between vegetation and soil breaks down, and this leads to instability and a considerable deterioration in soil quality (Adejuwon and Ekanade, 1987). A change in the chemical properties of the topsoil compared to the subsoil is attributed to the lateral structure of cocoa root, as a surface feeder, the impact of litterfall and negligible leaching processes in cocoa ecosystem. This supports Thong and Ng (1978); Wood and Lass (1985) and Hartemink (2005) that most cocoa roots are found in the top $30 \mathrm{~cm}$, deep capture of nutrients, which is important in many permanent cropping systems. A change is soil chemical properties under perennial crops found to be different were related to the fact that soils, crops and climates were different. Also, the change in soil chemical properties may reflect the decrease in nutrient stocks of the soil, but it also reflects immobilization of nutrients in the biomass. Single species tree plantation according to Aweto (2001) immobilized soil nutrient faster and return less nutrients to the soil than rainforest.

Conclusion: Using index of deterioration to evaluate the soil nutrient status in cocoa species shows the existing variation due to the differences in nutrient uptake. Although calcium is the most available nutrient in Nigerian alfisol and immobile in the soil unlike other macronutrients, the study confirmed that, hybrid cocoa species uptake high quantity of $\mathrm{Ca}$ and $\mathrm{N}$ from the soil compared to the indigenous type. Therefore, it is concluded that cocoa species influence soil properties differently in the same geographical location due to the variation in the nutrient uptake and return dynamic.

\section{REFERENCES}

Afolayan, OS (2016). Comparative Analysis of Nutrient Status in Indigenous and Hybrid Cocoa Farms in Tropical Rainforest Agroecological Zone of Nigeria. An Unpublished Ph.D Thesis, University of Ilorin Nigeria.

Aikpokpodion, PE (2010). Nutrient Dynamics in Cocoa Soils, Leaf and Beans in Ondo State, Nigeria. J. of Agri. Sci.1 (1):01-09.

Aweto, AO (2001). Impact of Single Species Tree Plantations on Nutrient Cycling in West African Rainforest and Savanna Ecosystems. Inter. J. of Sus.Dev.8: 356-368.
Aweto, AO; Obe, O; Ayanniyi, OO (1992). Effects of Shifting Cultivation and Continuous Cultivation of Cassava (Manihot esculenta) Intercropped with Maize on a Forest Alfisol in South Western Nigeria. J. of Agri. Sci. 118:195-198.

Barrios, E; Schroth, J (2003). Soil Nutrient Availability and Acidity. In: G Schroth et al. (Eds.) Trees, Crops and Soil Fertility Concepts and Research Methods. CABI, Wallingford.

Beer, J; Muschler, R; Kass, D; Somarriba, E (1998). Shade Management in Coffee and Cocoa plantations. Agrofor. Sys. 38:139-164.

Black, CA (1965). Methods of Soil Analysis ll. American Society of Agronomy, Madison, WI.

Bouyoucos, GJ (1962). Estimation of the Colloidal Material in Soils. Soil Sci. N.J.

Bray, RH; Kurtz, LT (1945). Determination of Total Organic and Available Forms of Phosphorus in Soil. Soil Science, 59:39-45.

Bray, RH (1954). Nutrient Mobility Concept of SoilPlant Relationships. Soil Sci. 104:9- 22.

Bremner, JM (1965). Total Nitrogen. In: Black, CA (Ed.) Methods of Soil Analysis. American Society of Agronomy, Madison.

De Oliveira, LJ; Valle, RR (1990). Nutrient Cycling in the Cocoa Ecosystem: Rain and Throughfall Sources for the Soil and the Cacao Tree. Agri. Ecosys. \& Environ.32:143154.

Ekanade, O (1985). The Impact of Cocoa Cultivation on Soil Characteristics in Southwestern Nigeria. Unpublished Ph.D. University of Ife.

Ekanade, O (2011). Biogeographical Development and Environmental Issues in Nigeria. In: TS Ayobami; OO Orimogunje (2011). Environmental Research and Challenges of Sustainable Development in Nigeria. Obefemi Awolowo UnivPress, Ile-Ife, Nigeria.

Fisher, RF (1995). Amelioration of Degraded Rainforest Soils by Plantations of Native Trees. Soil Sci. Soc. of Amer. J. 59, 544-549. 
Gershmel, PJ (1976). An Alternative Biogeography. Annals of the Ass. of Amer. Biogeo.66 (2):223241.

Hartemink, AE (2005). Nutrient Stocks, Nutrient Cycling and Soil Changes in Cocoa Ecosystems: A Review. Adv. in Agro.6:227-253.

Henry, DF (1990). Fundamentals of Soil Science. $8^{\text {th }}$ Ed.. John Wiley and Sons. NY.

Isaac, AR; Korber, JD (1971). Atomic Absorption and Flame Photometry; Techniques and Issues in soil, Plant and Water Analysis. In: IM Saish (Ed.) Instrumental Methods for Analysis of Soil and Plant Issues. Soil Sci. Soc. of Amer. Publication Inc., Madison.

National Population Commission (2006). Official Gazette of the Federal Republic of Nigeria, Federal Government of Nigeria.
Peech, M (1965). Methods of Soil Analysis 1l. Ameri Soc. of Agron. Madison, W.I.

Schroth, G and Sinclair, F.L. (2003). Trees, Crops and Soil Fertility. CABI, Wallingfold.

von Uexküll, HR (1986). Efficient Fertilizer Use in Acid Upland Soils of the Humid Tropics. FAO.

Walkey, A; Black, CA (1934). An Examination of Degtagereft Method for Determining Soil Organic Matter and a Proposed Modification of Chronic Acid Titration Method. Soil Service, 37, 29-38.

Wood, GAR; Lass, RA (1985). Cocoa (4 ${ }^{\text {th }}$ Ed). Longman Scientific and Technical, Essex. 